\title{
DIGITALISING ASSET MANAGEMENT: CONCOMITANT BENEFITS AND PERSISTENT CHALLENGES
}

\begin{abstract}
Purpose: Advancements in digital technologies have provided significant opportunities to improve the Architecture, Engineering, Construction and Owner-operated (AECO) sector's performance through superior data management, streamlined processes and cooperative working practices. However, whilst academic literature widely espouses these benefits during the design and construction phases of development, research suggests that the operational phase of a building's lifecycle has yet to fully realise performance improvements available through the application of digital modelling technology. This paper synthesises extant digital modelling, asset management and emergent digital asset management literature, to report upon the beneficial implications of digitalised asset management and identify obstacles hampering its adoption in industry.
\end{abstract}

Approach: A componential synthesis of future work reported upon in extant literature is organised into thematic categories that indicate potential research avenues and a trajectory for digital asset management research and practice.

Findings: Themes identified include: i) imprecise BIM definitions; ii) isolated software development; iii) data interoperability; iv) intellectual property (IP) and virtual property (VP) rights; and vi) skills and training requirements. Notably, increased environmental performance also arose as a theme requiring further research but received considerably less academic coverage than the other obstacles identified.

Originality/ value - The work presents a comprehensive review of digital technologies utilised within the AECO sector and as such provides utility to researchers, policy makers and practitioners to enhance their knowledge capabilities.

\section{KEYWORDS}

Digital Built Environment, Building Information Modelling, Asset Management, Whole Lifecycle Development, AECO Efficiencies and Environmental Sustainability.

\section{INTRODUCTION}

The Architecture, Engineering, Construction and Owner-operated (AECO) sector has traditionally been beset with issues surrounding stakeholder communication, process efficiencies and built asset performance during the operational phase of building occupancy 
(Arayici and Coates, 2012; Olatunji and Akanmu, 2014; Lindkvist, 2015; Pärn et al, 2016). However, the advent of digital modelling in recent years has presented significant opportunities to improve upon these persistent issues. Increased efficiency and collaboration realised through the implementation of the disruptive technology 'Building Information Modelling' (BIM) has led to governments mandating BIM as an industry standard - the UK Government being a prominent example (British Standard 1192, 2016; Race, 2013; Eadie et al, 2014; Mehran, 2016). Consequently, the AECO sector has become increasingly digitalised, engendering concomitant benefits in terms of superior efficiencies and organisational collaboration over the whole life-cycle of development (Eadie et al, 2013; Czmoch and Pekala, 2014; Yang et al, 2016a). The increasing sophistication of digital technologies such as: BIM (Eastman et al, 2011; Race, 2013; Barnes and Davies, 2014; Kensek, 2014a); BIM tag technology (Motamedi, et al, 2011; Thomson and Boehm, 2015); environmental sensors (Kensek, 2014b); and laser scanning technology (Chan et al, 2016; Yang et al, 2016a) indicates that a larger 'digital built environment' movement is underway (c.f. Bojanova, 2014; Brooke, 2016; Scholz, 2016; Pärn and Edwards, 2017).

Although the beneficial implications of digital modelling in the AECO sector are well espoused in academic literature, the main focus has been the design and construction phase of development. The building's operational 'in-use' phase has received comparatively scant academic attention, yet is the chief contributor to the building's whole lifecycle cost and performance (Bosch et al, 2014; Kessem et al, 2014; Liu and Issa, 2014; Lindkvist, 2015; Nical and Wodynski, 2016). Consequently, asset management is now progressively gaining considerable academic and practitioner interest particularly in terms of exploiting the beneficial implications of BIM implementation (Arayici and Coates, 2012; Olatunji and Akanmu, 2014; Lindkvist, 2015; Pärn et al, 2016).

Pärn et al, (2017) and Dubé et al, (2005) have suggested BIM is displacing traditional AECO practices and replacing them with virtual communities of practice. This is particularly relevant for asset management organisations who see technological development as a vehicle for delivering increased efficiency and value (Love et al, 2014). Mohandes et al, (2014) contend that the data management potential of BIM affords a panacea to asset management issues inherent within the ever increasing quantity and complexity of information gathered throughout a building's lifecycle. BIM implementation can therefore support facility managers by complementing strategic and tactical skills requirements needed to manage an 
amorphous range of facilities management (FM) requirements (McGregor and Then, 1999; Atkin and Brooks, 2005; Azhar et al, 2011).

Such implementation will require the resolution of persistent issues that cumulatively have prevented the wider adoption of digital technologies within asset management. This review brings together extant literature on digital modelling within the AECO sector, contemporary asset management and emergent digital asset management. A critical overview of digital modelling presents: i) a succinct account of its beneficial implications when applied to asset management; and ii) identifies factors currently hindering industrywide implementation of digital asset management. In realising these aims, the objective is to garner a consensus from commentators participating in the digitalised AECO discourse regarding both the practical and research based requirements for increased digitalisation of the AECO sector. The research concludes by proposing: future developments of BIM in asset management; the need for greater inclusion of environmental sustainability issues; and the need to integrate sensor based technologies to assist facility managers in optimising decisions for asset management.

\section{RESEARCH APPROACH}

An interpretivist research approach to reviewing extant literature was adopted that contained elements of positivism, where the latter was founded upon the assumption that published material has already been scientifically verified by a robust peer review process. From an operational perspective, published materials contained within Birmingham City University's (BCU) Summon, BCU Open Access Repository and Research Gate databases were comprehensively reviewed. Three lines of academic enquiry were pursued, namely: i) asset management literature; ii) digital modelling literature; and iii) emergent digital asset management literature. This approach led organically to a structure comprising: i) the wider beneficial implications of a digitalised AECO sector; ii) the implications of digitalised asset management; and iii) obstacles impeding widespread digital modelling implementation in practice.

A qualitative componential synthesis of published literature sought to thematically group the subject matter of papers published and ascertain the trajectory of future research into digital asset management (see Figure 1). Thematic groupings were: BIM implementation; generative design; BIM data implications; BIM performance analysis; BIM for asset management; design for maintenance; and knowledge transfer and skill requirements. Where future 
research suggestions were offered, they were interpreted by the research team and clustered into eight logical headings, namely: improvement to industry data interoperability; increased collaborative working at the organisational level; increased collaborative working at the individual/actor level; refinement of processes and management practices; resolution of implementation difficulties; increased performance measurement and analysis; increased industry skill levels; and increased environmental sustainability of development. Each heading represents an avenue for improving the functionality, performance and accessibility of digitalised asset management within the AECO sector. Collating and analysing the literature in this way allows a richer understanding of which journals focus on which issues.

The three most frequently suggested research paths, in descending order were: i) increased performance measurement and analysis; ii) improvement to industry data interoperability; and iii) increased collaborative working at the organisational level. Whilst these issues have overarching implications for digital modelling implementation in general, they impact considerably upon implementation of digital modelling in asset management. Furthermore, the apparent academic significance placed upon these research requirements, indicates efforts to resolve them would bring immediate benefits to the AECO sector. Notably, the most frequently suggested research path regarding 'increased performance measurement and analysis' correlates with integrating technological developments such as: BIM tag technology (Motamedi, et al, 2011; Thomson and Boehm, 2015); environmental sensors (Kensek, 2014b); laser scanning technology (Chan et al, 2016; Yang et al, 2016a); and utilisation of wireless networks (Riaz et al, 2014). The incorporation of these technologies into BIM enabled developments can greatly enhance the development process, particularly regarding asset management during the operational phase.

The next three research paths suggested within the synthesis, all with equal weighting, were: i) resolution of implementation difficulties; ii) refinement of processes and management practices; and iii) increased environmental sustainability of development. Whilst these implications received lower attention, they all have an important role to play in terms of increasing the AECO sector's performance. The relatively low significance assigned to resolving implementation issues may be explained in terms of the three most prominent research paths all contributing to easing implementation difficulties. 


\section{DIGITALISING THE BUILT ENVIRONMENT}

Traditionally, the design, construction and occupation phases of a development have operated in relative isolation to each other with architects producing designs, contractors delivering the development and facility managers operating and maintaining the building (Race, 2013; Garber, 2014; Liu and Issa, 2014; Motawa and Almarshad, 2015). Exchanging information between members of the project management team (PMT) using paper records and outputs from differing systems can introduce human error and data incompatibility, hindering the efficiency of a development (Martin, 2011; Kivits and Furneaux, 2013; Motawa and Almarshad, 2013; Pătrăucean et al, 2015; Thomson and Boehm, 2015; Love et al, 2016a; Yang et al, 2016a). Diminished efficiency instigates spiralling costs and scaling back of initial design objectives as well as more complex innovations, particularly regarding the environmental provisions within a development (Atkin and Brooks, 2005). Whilst lines of communication are clear, interaction between members of the PMT can foster adversarial relations when individuals seek to mitigate their liability (Khosrowshahi and Arayici, 2012; Jiao et al, 2013; Barnes and Davies, 2014). In addition, facility managers are rarely consulted during the design or construction phases of a project's development and so the opportunity to maximise upon their tacit knowledge of data and information requirements for a building inuse is lost.

Application of advanced digital technologies (including BIM) to the design and construction phases of development has afforded extensive benefits. The ability to create a digital representation of a physical asset allows all development stakeholders to exchange knowledge, and coordinate the complex processes characteristic of development, using a single digital resource (Eastman et al, 2008; Czmoch and Pekala, 2014; Garber, 2014). Digital design affords numerous improvements to traditional AECO design practices in terms of iterative design, parametrics and extensive prefabrication. Iterative design for example, encompasses a cyclical process to facilitate constant testing, analysing and refining throughout the design phase of a development, a process which would require substantial time and resources if not undertaken digitally (Garber, 2014).

As digitisation has progressed at a rapid pace, conceptual designs are increasingly amalgamated with mathematical algorithms and parametric constraints expanding the remit of digital design into the realms of generative design (Abrishami et al, 2014; Abrishami et al, 2015). Generative design facilitates consideration of the relationships between different 
components throughout the design process, as evidenced by BIM's ability to detect potential clashes between components (e.g. ductwork passing through structural steel) before commencement of construction (Garber, 2014; Abrishami et al, 2015). The use of intelligent data, such as parametrics, requires dimensions to be assigned to generic form, and sets BIM apart from the two-dimensionally based CAD systems from which it evolved (Barnes and Davies, 2014; Ghaffarianhoseini et al, 2016). Consequently, BIM deals with both geometric and increasing quantities of non-geometric information (Brilakis et al, 2010). This innovation allows design issues traditionally encountered during the construction phase of a development to be identified and amended before a development commences.

Race (2013) describes BIM as: incomplete in terms of its ability to amalgamate a combination of constituent components; and infinite in terms of its almost limitless potential for collection and inclusion of building data. Through BIM utilisation, development stakeholders can readily access and utilise a digital representation of both the physical and functional characteristics of an asset (Rahman et al, 2016). AECO tasks are simplified, particularly at the design phase of development, thus optimising financial and time efficiency gains (Eadie et al, 2013; Czmoch and Pekala, 2014; Yang et al, 2016a). Consequently, BIM is considered to offer a potential remedy to the construction industry's susceptibility to economic recession, prompting the UK Government to commit to implementing BIM as a basic standard for all national infrastructure projects by 2016 (Race, 2013; BIM Task Group, 2013; Eadie et al, 2014; Kessem, 2014; Lindkvist, 2015; Mehran, 2016). This is especially pertinent considering that the sector has undergone a period of introspection regarding performance and productivity levels in recent decades (Babič et al, 2010; Underwood and Isikdag, 2011; Li et al, 2013; Love et al, 2013; Fox, 2014; Lu et al, 2015; Rogers et al, 2015).

Digital modelling facilitates greater continuity between the various systems and actors throughout the built environment life-cycle (Bosch et al, 2014; Olatunji and Akanmu, 2014; Lindkvist, 2015; Pătrăucean et al, 2015). Palpable benefits afforded by a BIM model include: accurate costing information throughout the development (Azhar et al, 2011; Barnes and Davies, 2014); opportunities to capitalise upon off-site prefabrication thus aiding in the delivery of an efficient and cost effective development (Azhar et al, 2011; Eastman et al, 2008; Race, 2013); and availability of data from a development for the purposes of informing future developments, representing a significant opportunity to improve knowledge transfer between different AECO projects (Kensek and Noble, 2014; Göçer et al, 2015; Grover and 
Froese, 2016). Furthermore, the increasing sophistication of digital modelling technologies (c.f. Eastman et al, 2011; Race, 2013; Barnes and Davies, 2014; Kensek, 2014a) presents a wealth of opportunities to increase the quantity and quality of information gathered regarding a BIM enabled built environment asset. Technological developments such as: BIM tag technology (Motamedi, et al, 2011; Thomson and Boehm, 2015); environmental sensors (Kensek, 2014b); and laser scanning technology (Chan et al, 2016; Yang et al, 2016a) can rapidly generate building data to inform both the construction and operation phases of development, as well as increasing opportunities to inform future developments. Wireless networks (c.f. Riaz et al, 2014) offer a means of utilising and integrating any information generated from these technological advancements for use in a built asset digital model.

The innate data storage capabilities of digital modelling have also had a major impact upon the AECO sector. Within BIM, entire planes through a design are subdivided into individual graphic tablets and arranged in a grid format, each tablet containing all applicable information for that specific section of the development. The larger the development the more tablets a plane may contain, with the only real restriction being the computing power of the system operating the virtual model (Race, 2013). This also has beneficial implications of embedding product and asset information into a 3D model (Succar, 2009), highlighting the development of a dual approach for both storing and exchanging information through BIM. However, stringent quality control protocols are required which do not impede the speed and frequency of updates when either incorporating new, or updating existing, information on tablets (Race, 2013). Process data streams (or building information) are dynamic, allowing for data sharing as well as constant transformations; conversely, archival repositories or record BIM is a means of storing data in its contractual state (Kensek, 2014a).

\section{Cloud Computing and Standards}

The advent of advanced cloud technology has had significant implications for the development of digital modelling and its potential applications in practice. Cloud computing technology facilitates the delivery of information technology services retrieved from the internet using web-based tools and applications vis-a-vis direct connection to a server (Race, 2013). Benefits accrued include: augmented business agility; improved capital and revenue expenditure; business scalability and agility; faster development and deployment of software applications; and importantly a managed but outsourced IT capability (Redmond et al, 2012; 
Jardim-Goncalves and Grilo, 2010; Chen et al, 2016). There are three levels at which clouds operate:

- Infrastructure as a Service (IaaS) - the base level of cloud function, which incorporates server space, data storage, networking facilities and the capacity to operate a number of systems such as Linux, Windows and Solaris (Race, 2013).

- Platform as a Service (PaaS) - incorporates the same functionality as IaaS but with the addition of software tools which allow bespoke applications to be created within the context of an organisation's objectives, customisations of Gmail, Google Calendar and Google Docs (Chen et al, 2016).

- Software as a Service (SaaS) - incorporates all the functions of IaaS and PaaS, but with greater focus upon facilitating specific needs of business users (Chen et al, 2016). Accounting software, for instance, can be prohibitively expensive for many organisations; SaaS can provide generalised accounting software for individual cloud users (Race, 2013).

Many organisations agree that collaborative cloud options available through an integrated BIM platform are advantageous, particularly regarding the potential to benchmark asset performance (Du et al, 2014). Traditional rudimentary evaluation tools currently available (including the BIM Maturity Matrix, BIM excellence (BIMe) and the Interactive Capacity Maturity Model (ICMM)) do not facilitate the same levels of competitive analysis of BIM performance across industry peers (c.f. Succar, 2009; Succar et al, 2012; Du et al, 2014). BIM data and information in a multidisciplinary collaborative environment requires stringent control and is currently governed by three overriding standards:

- $\mathrm{CI} / \mathrm{SfB}$ (1962) - predominantly aimed at classifying and structuring information for use in construction projects. Information is categorised by: physical environment; elements; construction forms; materials; and finally activities and requirements. Although antiquated, it remains a relevant standard.

- Uniclass (1997) - a similar system to $\mathrm{Cl} / \mathrm{SfB}$ but it provides a greater range of classifications. It is based upon the more recent (but now obsolete) ISO TR 14177.

- BS 1192 (2007) - seeks to aid the production of information specifically in the architectural sector. This standard offers guidance on the construction of a communal 
pool of information and provides facilities to interact with both private and public repositories of data (c.f. Race, 2013; Xue et al, 2015).

\section{DIGITAL ASSET MANAGEMENT}

To optimise the business and working environment, an organisation's facilities must be managed effectively to avoid severe business performance reductions (Atkin and Brooks, 2005). Asset management, in context to its role within the larger field of FM, supports core business objectives of an organisation regarding the functionality of its buildings and infrastructure (Lehtonen and Salonen, 2005; Jensen et al, 2012; Steenhuizen et al, 2014; Nical and Wodynski, 2016). Although asset management is traditionally viewed as simply maintenance, cleaning and general care-taking (Meng, 2014), it incorporates a variety of interrelated multidisciplinary functions and disparate management systems, which must operate in an integrative manner (Waheed and Fernie, 2009; Barret and Finch, 2014; Kessem et al, 2014; Mohandes et al, 2014; Ilter and Ergen, 2015; Cao et al, 2016; Nical and Wodynski, 2016). Many organisations are appreciating the benefits of an efficient and crucially innovative asset management operation in a constant striving towards achieving 'best value' (Scupola, 2012, c.f. Kashiwagi and Savicky, 2003; Atkin and Brooks, 2005; Jensen et al, 2014). A holistic approach to asset management is therefore required that accounts for interdependent factors supporting business growth, prosperity and best value such as financial efficiency ('sweating' physical assets), allowances for future changes in the provision of space, and providing the best possible environment for the organisation's core business and workforce (Atkin and Brooks, 2005; Barrett and Finch, 2014). Whilst the integration of BIM with FM and asset management is currently less established than the design and construction aspects of development, the potential to extract and analyse information stored in BIM to improve FM delivery is undeniable (Bosch et al, 2014; Kessem et al, 2014; Love et al, 2014).

Deployment of digital modelling in asset management can greatly improve the quality of data transfers between development stakeholders (Jiao et al, 2013; Lindkvist, 2015; Khaddaj and Srour, 2016). Traditional, manual handover of data often leads to inaccuracies (or worse, loss of data), diminishing the operational information held on a building during its lifecycle (Lindkvist, 2015; Motawa and Almarshad, 2015; Love et al, 2016a). Studies have shown that facility owners regularly encounter incomplete as-built data documentation, fostering 
dissatisfaction, particularly where transferred operations and maintenance (O\&M) data proves wholly unsuitable for asset management (Mayo and Issa, 2016). The management of information remains a vexatious and complicated issue within the AECO sector as significant effort is invested into replicating resources and unintentionally supporting inefficient workflows (Jiao et al, 2013; Kessem et al, 2014).

To address these issues, attempts have been made to utilise the inherent capabilities of digital modelling to coordinate consistent and computable building data throughout a building's lifecycle (Underwood and Isikdag, 2011; Becerik-Gerber et al, 2012; Gheisari and Irizarry, 2014; Love et al, 2014). Chong et al, (2016) suggest that BIM provides a vehicle for improving data reliability and quality while other researchers suggest that BIM implementation in asset management provides the efficient capture of building information (i.e. systems, spaces, finishes) in a digital format (Ilter and Ergen, 2015; Kessem et al, 2014).. Asset information replication can be minimised through the storage of manufacturers' product data within 3D parametric objects (Kessem et al, 2014). A BIM-compliant database assists facility managers in various duties such as commissioning and closeout, energy management, maintenance and repair, quality control and assurance as well as space management (Becerik-Gerber et al, 2012). Efforts to create an integrated data sharing platform utilising BIM, have resulted in the development of software applications such as project lifecycle information modelling (PLIM) (Race, 2013). Data utilised in the construction phase of development is often revised before completion of the construction process. Use of a specially designed BIM for asset management application such as PLIM, can aid in managing and storing this revised data for FM purposes (Jiao et al, 2013). Furthermore, widespread collection of building asset data facilitated through BIM adoption will increase performance comparison and benchmarking, ensuring continuous performance improvement in the future (Giel and Issa, 2016).

Some estimates place 85 per cent of the total lifecycle cost of a development occurring during the operational phase, highlighting the potential of BIM driven asset management to improve upon built asset performance, particularly regarding cost efficiencies over the course of a building's lifecycle (Korpela et al, 2015). This has led some clients and building operators to require increases in a development's economic and environmental efficiencies (Kessem et al, 2014). Despite this compelling statistic, BIM developments have mainly focussed upon new buildings, which make up between 1 and 2 per cent of the total building stock annually (Volk 
et al, 2013, Kessem et al, 2014; Diaz-Vilariño et al, 2015). To date, the opportunity to optimise life cycle cost management of built assets has largely been missed.

\section{Environmental Sustainability}

Digital modelling has significant potential to improve the AECO sector's environmental performance. Sustainability is defined by the Brundtland commission (1987) as: "development that meets the needs of the present without compromising the ability of future generations to meet their own needs." Practitioners and clients within the AECO sector are under increasing pressure to provide value for money throughout the development process but in a sustainable manner (Arayici et al, 2011; Welle et al, 2011; Boyes, 2015; Göçer et al, 2015; Nardelli et al, 2015; Araszkiewicz, 2016). Similarly, facility managers are increasingly aware of the benefits of effectively executed maintenance management and efficient energy consumption (Liu and Issa, 2014). 40 per cent of global primary energy and more than 30 per cent of total global $\mathrm{CO}_{2}$ emissions are directly linked to building lifecycles, placing the annual emissions higher than those of either the transport or industrial sectors (Costa et al, 2013; Yung and Wang, 2014; Min et al, 2016; Mousa et al, 2016).

To achieve sustainability an organisation must manage the three aspects of social, financial and environmental performance (Yung and Wang, 2014; Chong et al, 2016). While much attention regarding digital asset management is focused upon efficiency, cost-savings and collaboration, there is considerably less discussion regarding the environmental aspect of sustainability, such as deconstruction emissions and recycling rates (Volk et al, 2013). Nevertheless, BIM adoption may offer vital aid in meeting perennial challenges regarding quality, efficiency, productivity and sustainable development (Arayici et al, 2011; Kivits and Furneaux, 2013; Li et al, 2013; Rogers et al, 2015). Many practices currently employed by the AECO sector are unnecessarily inefficient, presenting significant opportunities to generate major savings, particularly regarding O\&M activities (Liu and Issa, 2014). Exemplars such as the Sydney Opera House illustrate that building sustainability ratings may be improved through BIM compliant asset management (Ballesty et al, 2007; Baharum and Pitt, 2009; Volk et al, 2013). Through the utilisation of retrospective BIM, benefits ordinarily attributed to contemporary BIM developments (such as integrated building, maintenance and management data storage and retrieval) can be leveraged to improve both data integrity and productivity (Ballesty et al, 2007; Love et al, 2016b). 


\section{OBSTACLES TO THE IMPLEMENTATION OF DIGITAL ASSET MANAGEMENT}

Despite the plethora of beneficial implications attained through digitalised AECO practice, a number of recurring issues can hinder whole-scale implementation in practice, namely: i) imprecise BIM compliance definitions (Barlish and Sullivan, 2012; Succar et al, 2012; Alwan and Gledson, 2014; Smith, 2014); ii) isolated software development (Eastman et al, 2011; Race, 2013); iii) data interoperability (Becerik-Gerber et al, 2012; Ilter and Ergen, 2015); iv) intellectual property (IP) and virtual property (VP) rights (Jiao et al, 2012; Olatunji and Akanmu, 2014); and v) increased industry skill and training requirements (Atkin and Brooks, 2005; Arayici and Coates, 2012; Garber, 2014; Abrishami et al, 2015; Rahman et al, 2016). Notwithstanding the increasing prominence of BIM in academic literature, implementation in industry continues to prove a challenging endeavour (refer to Figure 2).

\section{Imprecise BIM compliance definitions}

There are various levels of BIM compliance, where each new level incorporates all the functions of the previous levels but then adds an additional layer of information (c.f. Barnes and Davies, 2014; Kensek, 2014a). The level at which an organisation aligns its BIM compliance directly affects the potential benefits it may expect to receive. However, definitions used to describe BIM compliance levels are varied and often contradictory which has prompted calls to develop a more complete, comprehensive and consistent industry-wide set of standard definitions to improve clarity in practice (Barlish and Sullivan, 2012; Succar et al, 2012; Alwan and Gledson, 2014; Smith, 2014). Imprecise definitions may adversely affect wider implementation of BIM compliance; table 1 highlights the differences and omissions in BIM compliance definitions between a selection of different commentators. 3D BIM through to 5D BIM share universally accepted definitions, with the exception of a few minor differences. From 6D BIM onwards, definitions diverge significantly (Yung and Wang, 2014; Nical and Wodynski, 2016). The UK Government has committed to BIM compliance for nationally driven developments and infrastructure, seeking to mitigate the sector's susceptibility to economic downturn whilst simultaneously driving the UK's ailing productivity levels through promotion of innovative new systems and working practices (Li et al, 2013; Race, 2013; Kessem, 2014). Whilst this commitment may engender appreciable benefits for practitioners, if compliance is aligned at a lower level, then benefits associated with higher compliance levels may be missed (such as integrated asset management and environmental sustainability through BIM). 


\section{Isolated software development}

The software development process may also adversely impact upon the widespread implementation of digital modelling. As BIM has evolved, software applications have been developed almost in tandem (Race, 2013). This is due to industry demand for readily available solutions which in turn stimulates software proliferation to fulfil that need (Chen $e t$ $a l$, 2016). When this software is subsequently implemented, new requirements may arise which were not initially apparent and further software applications are developed. This recurrent process continues unabated until multiple software solutions exist to meet industry requirements, each individually developed, funded and owned. There are numerous BIM software applications which perform various different functions (refer to Table 2). As a consequence, difficulties arise when attempting to combine and share the functionality of the individual software applications across multiple software platforms causing this functionality to become fragmented (Eastman et al, 2011). Software isolation is a prominent issue when implementing BIM during the design and construction phases of development and implementation of digital modelling in asset management will be similarly affected by the same issue (Kessem et al, 2014; Xu et al, 2016). The absence of multi-functional software solutions also has negative implications for BIM in asset management development and implementation because the cost of acquiring multiple software packages, particularly within the context of small to medium enterprises (SMEs), can be prohibitive (c.f. Dainty et al, 2017). A number of leading software developers purport to have developed a complete BIM system, offering the data management requirements crucial to a BIM data repository (Chen et $a l$, 2016). However, to have developed such a system at this early stage of BIM development, suggests an evolution of pre-existing CAD data management components (Race, 2013).

\section{Data interoperability}

The issues related to the software development process highlight the requirement for an industry-wide data standard, ensuring interoperability between systems and facilitating collaboration between development stakeholders (Linderoth, 2009; Singh et al, 2010). However, academic discourse points toward a disconnect in interoperability related to BIM format data across asset information systems including: computerised maintenance systems (CMMS); energy management systems (EMS); electronic document management systems (EDMS); and building automation systems (BAS) (Becerik-Gerber et al, 2012; Ilter and Ergen, 2015). The primary objective of any data management activity is to enable increased data interoperability, essentially allowing data generated by one party to be easily accessible 
for all participants (Jiao et al, 2013; Lindkvist, 2015; Khaddaj and Srour, 2016). In practice, and despite the desire for sharing capabilities amongst asset management applications, many existing systems support the individual asset management function for which they were designed, but leave the overall interoperability with other systems in a fragmented state often requiring manual input to facilitate any form of exchange (Becerik-Gerber et al, 2012; Counsell, 2012; Xu et al, 2016). Kessem et al (2014) suggests that there is a lack of an industry-wide process for updating a designed model with as-built information. Much of the data generated and stored in BIM over the course of a development is in a process of moving from an active to a non-active state (Jiao et al, 2013). To address these concerns and issues, new information standards may be required (Hooper, 2015) and further research is needed to develop a system to integrate and automate information in a cost, time and resource efficient manner (Brilakis et al, 2010; Akinade et al, 2015).

\section{Intellectual property (IP) and virtual property (VP) rights}

In relation to the interoperability of data, consideration of the implications of intellectual property (IP) rights and virtual property (VP) rights is crucial. IP and VP rights recognise the defence of rights afforded to the author or owner of an intellectual or virtual asset, as well as the duration and scope of those rights (Olatunji and Akanmu, 2014). Asset management data can be owned by one of a multitude of different organisations, enterprises and Government agencies; this data requires the same treatment, respecting the IP or VP rights of the owner or author (Jiao et al, 2013). However, property rights are an obstacle to the collaborative environment BIM promotes, particularly at the design phase of development (Olatunji and Akanmu, 2014). BIM in asset management can expect to encounter similar issues, for many organisations sharing IP and VP rights can seem counterintuitive in the context of protecting an organisation's product and operational data, despite the benefits of collaborative working processes. Furthermore, the question is raised as to which is the most appropriate development stakeholder in an AECO project to be made custodian of such information and control the data contributed by multiple disciplines simultaneously (Jiao et al, 2013; Olatunji and Akanmu, 2014). The contemporary trend for 'propertisation' of intellectual rights has asserted the importance of this issue from a legal perspective and the legal ramifications of IP and VP rights, within an increasingly collaborative and open AECO environment, require significant academic and practitioner attention (Carrier, 2004; Posner, 2005; Olatunji and Akanmu, 2015). Extant research has questioned the wisdom, in economic terms, of exclusive ownership and rights to an intellectual artefact, asking whether exclusive ownership promotes 
creativity and innovation, or stifles it through weakened competition and democracy (Olatunji and Akanmu, 2014). For many organisations, there are tangible benefits to controlling all their own project data, but this can be problematic in current practice (Jiao et al, 2013).

\section{Industry skills and training requirements}

The abundance of new functions and possibilities facilitated by digital modelling has advanced more rapidly than the required skills and understanding to fabricate the results; an issue not confined to the AECO sector (Garber, 2014). The consequence of rapidly advancing technological capabilities is that a fresh injection of suitably skilled professionals is required to deal with the myriad of prerequisite skills and competencies needed to effectively operate within interdisciplinary teams (Arayici and Coates, 2012; Abrishami et al, 2015; Rahman et al, 2016). Furthermore, as with the embracing of all new innovations, there will be a transitional period which demands an increased requirement for these new skills and the associated training (Atkin and Brooks, 2005). This can often be a discouraging implication for organisations when considering implementing digitalised systems, so the beneficial implications of adopting such technology must be emphasised and made clear to practitioners (Rahman et al, 2016).

\section{CONCLUSIONS}

The increasing digitalisation of the AECO sector has engendered many key benefits, including: cooperative working practices; democratised data; built asset performance analysis; and process management. Many of these advantages provide tangible solutions to persistent problems plaguing the sector. However, as is often the case, the resolution of one issue can lead to numerous further unforeseen issues. The implementation of digital modelling in asset management is no different. Significant variations are encountered in asset management software, particularly in terms of file formats; intended lifecycles of systems and data; and functionality of the software. To accomplish universal industry-wide adoption of digital asset management, major efforts will be required to bridge the considerable gaps which at present prevent the wholesale integration of technologies such as BIM, PLIM and CAFM.

In addition to specific digital asset management implementation difficulties, a number of overarching issues persist. To realise the advantageous implications of digital asset management, ongoing issues regarding data interoperability; software isolation; skills and 
training; IP and VP considerations as well as consistent digital modelling definitions must be resolved, or more precisely considering the scale of the task, not have effort to resolve them diminished. These problems are prominent in digital modelling literature regarding the design phase of development, but play just as important a role in the successful implementation of digital modelling in asset management.

Some commentators (c.f. Arayici et al, 2011; Welle et al, 2011; Costa et al, 2013; Casas et al, 2014; Yung and Wang, 2014; Boyes, 2015; Bu et al, 2015; Göçer et al, 2015; Nardelli et al, 2015; Araskiewicz, 2016; Ahuja et al, 2016; Mousa et al, 2016) argue that the real potential of BIM in asset management lies in its innate potential to help in delivering superior environmental sustainability value, as opposed to purely financial sustainability. The operational phase of a building lifecycle consumes the majority of natural resources, so this implication demands attention, particularly given the current introspection within the AECO sector regarding its vast environmental footprint. The alarming statistics regarding energy consumption of built environment assets over the course of their expected lifespans, have engendered interest, both in academia and in practice, in increasing sustainability values through digitalised asset management, extending the functionality of BIM right through a building's complete life-cycle (Motawa and Carter, 2013; Shoubi et al, 2014; Lui et al, 2015; Guo and Wei, 2016; Yang et al, 2016b). Improvements to the design and construction phase of development, collaborative working practices and data management applications for instance, could stimulate similar increases to asset management efficiency and concomitant reductions in O\&M costs (Martin, 2011; Kivits and Furneaux, 2013; Motawa and Almarshad, 2013; Pătrăucean et al, 2015; Thomson and Boehm, 2015; Love et al, 2016a; Yang et al, 2016a).

Despite the well documented difficulties of implementing new systems and working processes, the beneficial implications of pursuing digital modelling adoption in practice far outweigh avoiding innate implementation issues. When considered as part of a wider digital movement, digital modelling is having significant desirable impacts upon various other sectors, most notably the automotive and shipbuilding sectors. Furthermore, advancements in sensor technologies and wireless networks are steadily increasing the quantity and quality of information generated from BIM-enabled developments, information which can be utilised in the operational phase of a development and inform future developments. In consideration of the plethora of desirable implications realised through the implementation of digital 
modelling, failure to realise this potential would represent a missed opportunity to impact upon many of the persistent issues which plague the AECO sector. 


\section{REFERENCES}

Abrishami, S., Goulding, J., Rahimian, F.P., Ganah, A. and Sawhney, A. (2014) G-BIM Framework and Development Process for Integrated AEC Design Automation, Procedia Engineering, Vol. 85, pp. 10-17. DOI: 10.1016/j.proeng.2014.10.523

Abrishami, S., Goulding, J., Rahimian, F.P. and Ganah, A. (2015) Virtual Generative BIM Workspace for Maximising AEC Conceptual Design Innovation, Construction Innovation, Vol. 15, No. 1, pp. 24-41. DOI: 10.1108/CI-07-2014-0036

Ahuja, R. Sawhey, A. and Arif, M. (2016) Driving Lean and Green Project Outcomes Using BIM: A Qualitative Comparative Analysis, International Journal of Sustainable Built $\begin{array}{lllllll}\text { Environment, } & \text { Vol. } & \text { 6, } & \text { No. } & \text { pp. }\end{array}$ http://dx.doi.org/10.1016/j.ijsbe.2016.10.006

Akinade, O. O., Oyedele, L. O., Bilal, M., Ajay, S. O., Owolabi, H. A., Alaka, H. A. and Bello, S. A. (2015) Waste Minimisation Through Deconstruction: A BIM Based Deconstructability Assessment Score (BIM-DAS), Resources, Conservation and $\begin{array}{lllll}\text { Recycling, } & \text { Vol. } & 105, & \text { pp. }\end{array}$ http://dx.doi.org/10.1016/j.resconrec.2015.10.018

Alwan, Z. and Gledson, B. J. (2014) Towards Green Building Performance Evaluation using Asset Information Modelling, Built Environment Project and Asset Management, Vol. 5, No. 3, pp. 290-303. DOI: 10.1108/BEPAM-03-2014-0020

Araszkiewicz, K. (2016) Green BIM Concept - Scandinavian Inspirations, Archives of Civil Engineering, Vol. 62, No. 1, pp. 99-110. DOl: 10.1515/ace-2015-0054

Arayici, Y., Coates, P., Koskela, L., Kagioglou, M., Usher, C. and O'Reilly, K. (2011) Technology Adoption in the BIM Implementation for Lean Architectural Practice, Automation in Construction, Vol. 20, No. 2, pp. 189-195. DOI:10.1016/j.autcon.2010.09.016

Arayici, Y. and Coates, P. (2012) A System Engineering Perspective to Knowledge Transfer: A Case Study Approach of BIM Adoption, Virtual Reality - Human Computer Interaction, Available via: https://www.intechopen.com/books/virtual-reality-human-computerinteraction [Accessed: 10th October 2017].

Atkin, B. and Brooks, A. (2005) Total Facilities Management, 2nd edn. Singapore: Blackwell Publishing Ltd. ISBN: 1405127902

Autodesk (2014) Ecotect Analysis and Green Building Studio. Available via: https://knowledge.autodesk.com/support/ecotect- 
analysis/troubleshooting/caas/sfdcarticles/sfdcarticles/Ecotect-Analysis-and-GreenBuilding-Studio.html [Accessed: October 2017].

Autodesk (2016) Ecotect Analysis Discontinuation FAQ. Available via: https://knowledge.autodesk.com/support/ecotectanalysis/troubleshooting/caas/sfdcarticles/sfdcarticles/Ecotect-AnalysisDiscontinuation-FAQ.html [Accessed: October 2017].

Autodesk (2017a) Revit: Built for BIM. Available via: http://www.autodesk.com/products/revit-family/overview [Accessed: October 2017] Bentley (2017) Design Modeling Software. Available via: https://www.bentley.com/en/products/product-line/modeling-and-visualizationsoftware/microstation [Accessed: October 2017].

Autodesk (2017b) Navisworks: Project review software for AEC professionals. Available from: http://www.autodesk.com/products/navisworks/overview [Accessed: October 2017]

Azhar, S., Hein, M. and Sketo, B., (2011) Building Information Modelling (BIM): Benefits, Risks, and Challenges for the AEC Industry, Journal of Leadership Management in Engineering, Vol. 11, No. 3, pp. 241-252. DOI: https://doi.org/10.1061/(ASCE)LM.1943-5630.0000127

Babič, N. C., Podbreznik, P. and Rebolj, D. (2010) Integrating Resource Production and Construction using BIM, Automation in Construction, Vol. 19, pp. 539-543. DOI:10.1016/j.autcon.2009.11.005

Baharum, M. R. and Pitt, M. (2009) Determining a Conceptual Framework for Green FM Intellectual Capital, Journal of Facilities Management, Vol. 7, No. 4, pp. 267-282. DOI: $10.1108 / 14725960910990026$

Ballesty, S., Mitchell, J., Drogemuller, R., Schevers, H., Linning, C., Singh, G. and Marchant, D. (2007) Adopting BIM for Facilities Management: Solutions for Managing the Sydney Opera House, Brisbane: Cooperative Research Centre (CRC) for Construction Innovation.

Barlish, K. and Sullivan, K. (2012) How to Measure the Benefits of BIM - A Case Study Approach, Automation in Construction, Vol. 24, pp. 149-159. DOI: 10.1016/j.autcon.2012.02.008

Barnes, P. and Davies, N. (2014) BIM in Principle and Practice, London: ICE Publishing. ISBN: 9780727758637

Barret, P. and Finch, E. (2014) Facilities Management: The Dynamics of Excellence, 3rd Ed. West Sussex: Wiley Blackwell. ISBN: 1299964575 
Becerik-Gerber, B., Jazizadeh, F., Li, N. and Calis, G. (2012) Application Areas and Data Requirements for BIM-Enabled Facilities Management, Journal of Construction Engineering and Management, Vol. 138, No. 3, pp. 431-442. DOI: 10.1061/(ASCE)CO.1943-7862.0000433

BIM Task Group (2013) Government Soft Landings: Departmental Implementation Brief, BIM Task Group, London. Available via: http://www.bimtaskgroup.org/ [Accessed: 10th October, 2017].

Bojanova, I. (2014) The Digital Revolution: What's on the Horizon?, IT Professional, Vol. 16, No. 1, pp. 8-12. DOI:10.1109/MITP.2014.11

Bosch, A., Volker, L. and Koutamanis, A. (2014) BIM in the Operations Stage: Bottlenecks and Implications for Owners, Built Environment Project and Asset Management, Vol. 5, No. 3, pp. 331-343. DOI: 10.1108/BEPAM-03-2014-0017

Boyes, H. (2015) Security, Privacy and the Built Environment, IT Professional, Vol. 17, No. 3, pp. 25-31. DOI: 10.1109/MITP.2015.49

Brilakis, I., Lourakis, M., Sacks, R., Savarese, S., Christodoulou, S., Teizer, J. and Makhmalbaf, A. (2010) Toward Automated Generation of Parametric BIMs Based on Hybrid Video and Laser Scanning Data, Advanced Engineering Informatics, Vol. 24, pp. 456-465. DOI:10.1016/j.aei.2010.06.006

British Standard 1192 (2016) Collaborative Production of Architectural, Engineering and Construction Information: Code of Practice, London: British Standards Institution.

Brooke, H. (2016) Inside the Digital Revolution, Journal of International Affairs, Vol. 70, No. 1, pp. 29-53,. DOI: ?? Available via: https://search-proquestcom.ezproxy.bcu.ac.uk/docview/1855797544?accountid=10749 [Accessed: 10th October 2017]

Bu, S., Shen, G., Anumba, C. J., Wong, A. K. D. and Liang, X. (2015) Literature Review of Green Retrofit Design for Commercial Buildings with BIM Implication, Smart and Sustainable Built Environment, Vol, 4, No. 2, pp. 188-214. DOI: 10.1108/SASBE-082014-0043

Cao, D., Li, H., Wang, G., Luo, X., Yang, X. and Tan, D. (2016) Dynamics of Project-Based Collaborative Networks for BIM Implementation: Analysis Based on Stochastic ActorOrientated Models, Journal of Management in Engineering, Vol. 33, No. 3 pp. 1-12. DOI: 10.1061/(ASCE)ME.1943-5479.0000503

Carrier, M. A. (2004) Cabining Intellectual Property Through a Property Paradigm, Duke Law Journal , Vol. 54, No. 1, pp. 1-145. DOI: 10.2307/40040481. 
Casas, P. F., Casas, A. F., Garrido-Soriano, N. and Casanovas, J. (2014) Formal Simulation Model to Optimise Building Sustainability, Advances in Engineering Software, Vol. 69, pp. 62-74. DOI: http://dx.doi.org/10.1016/j.advengsoft.2013.12.009

Chan, B., Guan, H., Jo, J., Blumenstein, M. and Wang, J. (2016) Defining a Conceptual Framework for Integration of Modelling and Advanced Imaging for Improving Reliability and Efficiency of Bridge Assessments, Journal of Civil Structural Health Monitoring, Vol. 6, pp. 703-714. DOI: 10.1007/s13349-016-0191-6

Chen, H. M., Chang, K. C. and Lin, T. H. (2016) A Cloud Based System Framework for Performing Online Viewing, Storage, and Analysis on Big Data of Massive BIMs, Automation in Construction, Vol. 71, pp. 34-48. DOI: http://dx.doi.org/10.1016/j.autcon.2016.03.002

Chong, H. Y., Lee, C. Y. and Wang, X. (2016) A Mixed Review of the Adoption of Building Information Modelling (BIM) for Sustainability, Journal of Cleaner Production, pp. 113. DOI: http://dx.doi.org/10.1016/j.jclepro.2016.09.222

Costa, A., Keane, M. M., Torrens, I. and Corry, E. (2013) Building Operation and Energy Performance: Monitoring, Analysis and Optimisation Toolkit, Applied Energy, Vol. 101, pp. 310-316. DOI:10.1016/j.apenergy.2011.10.037

Counsell, J. (2012) Beyond Level 2 BIM, Web Portals and Collaboration Tools, 16th International Conference on Information Visualisation, 16th International Conference on Information Visualisation, Montpellier, France, 11-13 July 2012. DOI: 10.1109/IV.2012.88

Czmoch, I. and Pekala, A. (2014) Traditional Design versus BIM Based Design, Procedia Engineering, Vol. 91, pp. 210-215. DOI: 10.1016/j.proeng.2014.12.048

Dainty, A., Leiringer, R., Fernie, S. and Harty, C. (2017) BIM and the Small Construction Firm: A Critical Perspective, Building Research and Information, Vol. 45, No. 6, pp. 696-709. DOI: 10.1080/09613218.2017.1293940

Dassault Systemes (2017) Discover Catia. Available via: https://www.3ds.com/productsservices/catia/ [Accessed: October, 2017].

Diaz-Vilariño, L., Khoshelham, K, Martinez-Sánchez, J. and Arias, P. (2015) 3D Modeling of Building Indoor Spaces and Closed Doors from Imagery and Point Clouds, Sensors, Vol. 15, pp. 3491-3512. DOI:10.3390/s150203491

Du, J., Liu, R., Raja, R. A. and Issa, F. (2014) BIM Cloud Score: Benchmarking BIM Performance, Journal of Construction, Engineering and Management, Vol. 140, No. 11. pp. 1-13 DOI: 10.1061/(ASCE)CO.1943-7862.0000891 
Dubé, L., Bourhis, A., and Jacob, R., (2005) The Impact of Structuring Characteristics on the Launching Of Virtual Communities of Practice, Journal of Organizational Change Management, Vol. 18, No. 2, pp. 145-166. DOI: http://dx.doi.org/10.1016/j.autcon.2013.09.001

Eadie, R., Browne, M., Odenyinka, H., Mckeown, C. and McNiff, S. (2013) BIM Implementation Throughout the UK Construction Project Lifecycle: An Analysis, Automation in Construction, Vol. 36, pp. 145-151. DOI: http://dx.doi.org/10.1016/j.autcon.2013.09.001

Eadie, R., Browne, M., Odeyinka, H., McKeown, C. and McNiff, S. (2014) A Survey of Current Status of and Perceived Changes Required for BIM Adoption in the UK, Built Environment Project and Asset Management, Vol. 5, No. 1, pp. 4-21. DOI: 10.1108/BEPAM-07-2013-0023

Eastman, C., Teicholz, P., Sacks, R., and Liston, K. (2008) BIM Handbook: A Guide to Building Information Modelling for Owners, Managers, Designers, Engineers, and Contractors, 2nd Ed., New Jersey: Wiley. ISBN: 9780470541371

Ecodomus (2015) Digitalising the World's Capital Assets. Available via: http://ecodomus.com/ [Accessed: October, 2017].

Fox, S. (2014) Getting Real About BIM: Critical Realist Descriptions as an Alternative to the Naïve Framing and Multiple Fallacies of Hype, International Journal of Managing Projects in Business, Vol. 7, No. 3, pp. 405-422. DOI: 10.1108/IJMPB-12-2013-0073

Garber, R. (2014) BIM Design: Realising the Creative Potential of Building Information Modelling, Chichester: Wiley. ISBN: 1322229473

Ghaffarianhoseini, A., Tookey, J., Ghaffarianhoseini, A., Naismith, N., Azhar, S., Efimova, O. and Raahemifar, K. (2016) Building Information Modelling (BIM) Uptake: Clear Benefits, Understanding its Implementation, Risks and Challenges, Renewable and Sustainable Energy Reviews. DOI: http://dx.doi.org/10.1016/j.rser.2016.11.083

Gheisari, M. and Irizarry, J. (2014) Investigating Human and Technological Requirements for Successful Implementation of a BIM-based Mobile Augmented Reality Environment in Facility Management Practices, Facilities, Vol. 34, No. 1/2, pp. 69-84. DOI: 10.1108/F04-2014-0040

Giel, B. and Issa, R. R. A. (2016) Framework for Evaluating the BIM Competencies of Facility Owners, Journal of Management in Engineering, Vol. 32, No. 1, pp. 1-15 04015024. DOI: 10.1061/(ASCE)ME.1943-5479.0000378 
Göçer, Ö., Hua, Y. and Göçer, K. (2015) Completing the Missing Link in Building Design Process: Enhancing Post-occupancy Evaluation Method for Effective Feedback for Building Performance, Building and Environment, Vol. 89, pp. 14-27. DOI: http://dx.doi.org/10.1016/j.buildenv.2015.02.011

Graphisoft (2017) What is ARCHICAD? Available via: http://www.graphisoft.com/archicad/ [Accessed: October, 2017].

Grover, R. and Froese, T. M. (2016) Knowledge Management in Construction using a SocioBIM Platform: A Case Study of AYO Smart Home Project, Procedia Engineering, Vol. 145, pp. 1283-1290. DOI: 10.1016/j.proeng.2016.04.165

Guo, S. J. and Wei, T. (2016) Cost-effective Energy Saving Measures Based on BIM Technology: Case Study at National Taiwan University, Energy and Buildings, Vol. 127, pp. 433-441. DOI: http://dx.doi.org/10.1016/j.enbuild.2016.06.015

Hooper, M. (2015) BIM Standardisation Efforts: The case of Sweden, Journal of Information Technology in Construction, Vol. 20, pp. 332-346. Available via: http://www.itcon.org/papers/2015_21.content.08967.pdf [Accessed: 10th October 2017] Ilter, D. and Ergen, E. (2015) BIM for Building Refurbishment and Maintenance: Current Status and Research Directions, Structural Survey, Vol. 33, No. 3, pp. 228-256. DOI: 10.1108/SS-02-2015-0008

Jardim-Goncalves, R. and Grilo, A. (2010) SOA4BIM: Putting the Building and Construction Industry in a Single European Information Space, Automation in Construction, Vol. 19, pp. 388-397. DOI:10.1016/j.autcon.2009.11.009

Jensen, P. A., van der Voort, T. J. M., Coenen, C., von Felten, D., Lindholm, A. L., Nielsen, S. B., Riratanaphong, C. and Pfenninger, M. (2012) In Search for the Added Value of FM: What we Know and What we Need to Learn, Facilities, Vol. 30, No. 5/6, pp. 199-217. DOI: $10.1108 / 02632771211208486$

Jensen, P. A., van der Voort, T. J. M., Coenen, C. and Sarasoja, A. L. (2014) Reflecting on Future Research Concerning the Added Value of FM, Facilities, Vol. 32, No. 13/14, pp. 856-870. DOI: 10.1108/F-09-2012-0070

Jiao, Y., Wang, Y., Zhang, S., Li, Y., Yang, B. and Yuan, L. (2013) A Cloud Approach to Unified Lifecycle Data Management in Architecture, Engineering, Construction and Facilities Management: Integrating BIMs and SNS, Advanced Engineering Informatics, Vol. 27, pp. 173-188. DOI: http://dx.doi.org/10.1016/j.aei.2012.11.006

Kashiwagi, D. and Savicky, J. (2003) The Cost of 'Best Value' Construction, Journal of Facilities Management, Vol. 2, No. 3, pp. 285-295. DOI: 10.1108/14725960410808267 
Kensek, K. M. (2014a) Building Information Modeling, New York: Routledge. ISBN: 9781306661829

Kensek, K. M. (2014b) Integration of Environmental Sensors with BIM: Case Studies Using Arduino, Dynamo, and Revit API, Informes de la Construcción, Vol. 66, No. 536, pp. 1-9. DOI: $10.3989 /$ ic.13.151

Kensek, K. M. and Noble, D. (2014) Building Information Modeling: BIM in Current and Future Practice, New Jersey: Wiley. ISBN: 9781306731607

Kessem, M., Kelly, G., Dawood, N., Serginson, M. and Lockley, S. (2014) BIM in Facilities Management Applications: A Case Study of a Large University Complex, Built Environment Project and Asset Management, Vol. 5, No. 3, pp. 261-277. DOI: 10.1108/BEPAM-02-2014-0011

Khaddaj, M. and Srour, I. (2016) Using BIM to Retrofit Existing Buildings, Procedia Engineering, Vol. 145, pp. 1526-1533. DOI: 10.1016/j.proeng.2016.04.192

Khosrowshahi, F. and Arayici, Y. (2012) Roadmap from Implementation of BIM in the UK Construction Industry, Engineering, Construction and Architectural Management, Vol. 19, No. 6, pp. 610-635. DOI: 10.1108/09699981211277531

Kivits, R. A. and Furneaux, C. (2013) BIM: Enabling Sustainability and Asset Management through Knowledge Management, The Scientific World Journal, pp. 1-14. DOI: http://dx.doi.org/10.1155/2013/983721

Korpela, J., Miettinen, R., Salmikivi, T. and Ihalainen, J. (2015) The Challenges and Potentials of Utilising Building Information Modelling in Facilities Management: the Case of the Center for Properties and Facilities of the University of Helsinki, Construction Management and Economics, Vol. 33, No. 1, pp. 3-17. DOI: $10.1080 / 01446193.2015 .1016540$

Lehtonen, T. and Salonen, A. (2005) An Empirical Investigation of Procurement Trends and Partnership Management in FM Services: A Finnish Survey, International Journal of Strategic Property Management, Vol. 10, No. 2, pp. 65-78. DOI: $10.1080 / 1648715 X .2006 .9637545$

Li, J., Hou, L., Wang, X., Guo, J., Zhang, S. and Jiao, Y. (2013) A Project-based Quantification of BIM Benefits, International Journal of Advanced Robotic Systems, Vol. 11, No. 1231, pp. 1-13. DOI: $10.5772 / 58448$

Linderoth, H. C. J. (2009) Understanding Adoption and Use of BIM as the Creation of Actor Networks, Automation in Construction, Vol. 19, pp. 66-72. DOI:10.1016/j.autcon.2009.09.003 
Lindkvist, C. (2015) Contextualizing Learning Approaches which Shape BIM for Maintenance, Built Environment Project and Asset Management', Vol. 5, No. 3, pp. 318-330. DOI: 10.1108/BEPAM-03-2014-0018

Liu, R. and Issa, R. R. A. (2014) Design for Maintenance Accessibility Using BIM Tools, Facilities, Vol. 32, No. 3/4, pp. 153-159. DOI: 10.1108/F-09-2011-0078

Liu, S., Meng, X. and Tam, C. (2015) Building Information Modelling Based Building Design Optimization for Sustainability, Energy and Buildings, Vol. 105, pp. 130-153. DOI: http://dx.doi.org/10.1016/j.enbuild.2015.06.037

Love, P. E. D., Simpson, I., Hill, A. and Standing, C. (2013) From Justification to Evaluation: Building Information Modeling for Asset Owners, Automation in Construction, Vol. 35, pp. 208-216. DOI: http://dx.doi.org/10.1016/j.autcon.2013.05.008

Love, P. E. D., Matthews, J., Simpson, I., Hill, A. and Olatunji, O. A. (2014) A Benefit Realization Management Building Information Modeling Framework for Asset Owners, Automation in Construction, Vol. 37, pp. 1-10. DOI: http://dx.doi.org/10.1016/j.autcon.2013.09.007

Love, P. E. D., Zhou, J., Matthews, J. and Luo, H. (2016a) Systems Information Modeling: Enabling Digital Asset Management, Advances in Engineering Software, Vol. 102, pp. 155-165. DOI: http://dx.doi.org/10.1016/j.advengsoft.2016.10.007

Love, P. E. D., Zhou, J., Matthews, J. and Lou, H. (2016b) Object Orientated Modeling: Retrospective Systems Information Model for Constructability Assessment, Automation in Construction, Vol. 71, pp. 359-371. DOI: http://dx.doi.org/10.1016/j.autcon.2016.08.032

Lu, W., Fung, A., Peng, Y., Liang, C. and Rowlinson, S. (2015) Demystifying Construction Project Time-Effort Distribution Curves: BIM and Non-BIM Comparison, Journal of Management in Engineering, Vol. 31, No. 6. DOI: 10.1061/(ASCE)ME.19435479.0000356.

MagiCAD (2017) MagiCAD for Revit and AutoCAD. Available via: https://www.magicad.com/en/software/ [Accessed: October, 2017].

Martin, S. (2011) The Use of BIM in Asset Management, Area Development Site and Facility Planning, Vol. 46, No. 6, pp. 10. DOI: ?? Available via: https://search-proquestcom.ezproxy.bcu.ac.uk/docview/912208483?accountid=10749 (Accessed: 10th October 2017] 
Mayo, G. and Issa, R. R. A. (2016) Nongeometric Building Information Needs Assessment for Facilities Management, Journal of Management in Engineering, Vol. 32, No. 3, pp. 112. DOI: 10.1061/(ASCE)ME.1943-5479.0000414

McGregor, W. and Then, D. (1999) Facilities Management and the Business of Space, Butterworth-Heinemann: Oxford. ISBN: 9780340719640

Mehran, D. (2016) Exploring the Adoption of BIM in the UAE Construction Industry for AEC Firms, Procedia Engineering, Vol. 145, pp. 1110-1118. DOI: 10.1016/j.proeng.2016.04.144

Meng, X. (2014) Facilities Management: Tracing its Development Trajectory, Property Management, Vol. 33, No. 3, pp. 212-223. DOI: 10.1108/PM-12-2013-0059

Min, Z., Morgenstern, P. and Marjanovic-Halburd, L. (2016) Facilities Management Added Value in Closing the Energy Performance Gap, International Journal of Sustainable $\begin{array}{llllll}\text { Built } & \text { Environment, } & \text { Vol. } & \text { 5, }\end{array}$ http://dx.doi.org/10.1016/j.ijsbe.2016.06.004

Mohandes, S. R., Hamid, A. R. A. and Sadeghi, H. (2014) Exploiting Building Information Modelling Throughout the Whole Lifecycle of Construction Projects, Journal of Basic of Basic Applied Science, Vol. 4, No. 9, pp. 16-27. Available via: http://eprints.utm.my/59740/1/AbdulRahim2014_ExploitingBuildingInformationModeli ng.pdf [Accessed: 10th October 2017]

Motamedi, A., Saini, R., Hammad, A. and Zhu, B. (2011) Role-based Access to Facilities Lifecycle Information on RFID Tags, Advanced Engineering Informatics, Vol. 25, pp. 559-568. DOI: 10.1016/j.aei.2011.03.004

Motawa, I. and Almarshad, A. (2013) A Knowledge-based BIM System for Building Maintenance, Automation in Construction, Vol. 29, pp. 173-182. DOI: http://dx.doi.org/10.1016/j.autcon.2012.09.008

Motawa, I. and Almarshad, A. (2015) Case-based Reasoning and BIM Systems for Asset Management, Built Environment Project and Asset Management, Vol. 5, No. 3, pp. 233-247. DOI: 10.1108/BEPAM-02-2014-0006

Motawa, I. and Carter, K. (2013) Sustainable BIM-based Evaluation of Buildings, Procedia Social and Behavioral Sciences, Vol. 74, pp. 419-428. DOI: 10.1016/j.sbspro.2013.03.015

Mousa, M., Luo, X. and McCabe, B. (2016) Utilizing BIM and Carbon Estimating Methods for Meaningful Data Representation, Procedia Engineering, Vol. 145, pp. 1242-1249. DOI: 10.1016/j.proeng.2016.04.160 
Nardelli, G., Jensen, J. O. and Nielsen, S. B., (2015) Facilities Management Innovation in Public-private Collaborations, Journal of Facilities Management, Vol. 13, No. 2, pp. 185-203. DOI: 10.1108/JFM-04-2014-0012

Nical, A. K. and Wodynski, W. (2016) Enhancing Facility Management Through BIM 6D, Procedia Engineering. DOI: 10.1016/j.proeng.2016.11.623

Olatunji, O. A. and Akanmu, A, (2014) BIM-FM and Consequential Loss: How Consequential can Design Models be?, Built Environment Project and Asset Management, Vol. 5, No. 3, pp. 304-317. DOI: 10.1108/BEPAM-03-2014-0021

Pärn, E. A., Edwards, D. J. and Sing, M. C. P. (2016) The Building Information Modelling Trajectory in Facilities Management: A Review, Automation in Construction, Vol. 75, pp. 45-55. DOI: http://dx.doi.org/10.1016/j.autcon.2016.12.003

Pärn, E. A. and Edwards, D. J. (2017) Vision and Advocacy of Opteoelectronic Technology Developments in the AECO sector, Built Environment Project and Asset Management, Vol. 7, No. 3, pp. 330-348. DOI: 10.1108/BEPAM-11-2016-0081

Pătrăucean, V., Armeni, I., Nahangi, M., Yeung, J., Brilakis, I. and Haas, C. (2015) State of Research in Automatic As-built Modelling, Advanced Engineering Informatics, Vol. 29, pp. 162-171. DOI: http://dx.doi.org/10.1016/j.aei.2015.01.001

Posner, R. A. (2005) Intellectual Property: The Law and Economics Approach, The Journal of Economic Perspectives, Vol. 19, No. 2, pp. 57-73. DOI: 10.1257/0895330054048704 Race, S. (2013) BIM Demystified, 2nd Ed, London: RIBA Publishing. ISBN: 9781859465202 Rahman, R. A., Alsafouri, S., Tang, P. and Ayer, S. K. (2016) Comparing Building Information Modeling Skills of Project Managers and BIM Managers based on Social Media Analysis, Procedia Engineering, Vol. 145, pp. 812-819. DOI: 10.1016/j.proeng.2016.04.106

Redmond, A., Hore, A., Alshawi, M. and West, R. (2012) Exploring How Information Exchanges can be Enhanced Through Cloud BIM, Automation in Construction, Vol. 24, pp. 175-183. DOI:10.1016/j.autcon.2012.02.003

Rhinoceros (2017) Rhino 5 Features. Available via: https://www.rhino3d.com/features [Accessed: October, 2017].

Riaz, Z., Arslan, M., Kiani, and Azhar, S. (2014) CoSMoS: A BIM and Wireless Sensor Based Integrated Solution for Worker Safety in Confined Spaces, Automation in Construction, Vol. 45, pp. 96-106. DOI: http://dx.doi.org/10.1016/j.autcon.2014.05.010

Rogers, J., Chong, H. Y. and Preece, C. (2015) Adoption of Building Information Modelling technology (BIM): Perspectives from Malaysian engineering consulting services firms, 
Engineering, Construction and Architectural Management, Vol. 22, No.4, pp. 424-445. DOI: 10.1108/ECAM-05-2014-0067

Scholz, R. W. (2016) Sustainable Digital Environments: What Major Challenges Is Humankind Facing?, Sustainability, Vol. 8, No. 8, pp. 726-757. DOI: 10.3390/su8080726

Scupola, A. (2012) Managerial Perception of Service Innovation in Facility Management Organizations, Journal of Facilities Management, Vol. 10, No. 3, pp. 198-211. DOI: $10.1108 / 14725961211246009$

Shoubi, M. V., Shoubi, M. V., Bagchi, A. and Barough, A. S. (2014) Reducing the Operational Energy Demand in Buildings Using Building Information Modelling Tools and Sustainable Approaches, Ain Shams Engineering Journal, Vol. 6, pp. 41-55. DOI: http://dx.doi.org/10.1016/j.asej.2014.09.006

Singh, V., Gu, N. and Wang, X., (2011) A Theoretical Framework of a BIM-based Multidisciplinary Collaboration Platform, Automation in Construction, Vol. 20, pp. 134-144. DOI:10.1016/j.autcon.2010.09.011

SketchUp (2017) The Easiest Way to Draw in 3D. Available via: https://www.sketchup.com/ [Accessed: October, 2017].

Smith, P. (2014) BIM \& the 5D Project Cost Manager, Procedia Social and Behavioral Sciences, Vol. 119, pp. 475-484. DOI: 10.1016/j.sbspro.2014.03.053

Steenhuizen, D., Flores-Colen, I., Reitsma, A. G. and Lo, P. B., (2014) The Road to Facilities Management, Facilities, Vol. 32, No. 1/2, pp. 46-57. DOI: 10.1108/F-09-2012-0072

Succar, B. (2009) Building Information Modelling Framework: A Research and Delivery Foundation for Industry Stakeholders, Automation in Construction, Vol. 18, No. 3, pp. 357-375. DOI:10.1016/j.autcon.2008.10.003

Succar, B., Sher, W. and Williams, A. (2012) Measuring BIM Performance: Five metrics, Architectural Engineering and Design Management, Vol. 8, No. 2, pp. 120-142. DOI: http://dx.doi.org/10.1080/17452007.2012.659506

Thomson, C. and Boehm, J. (2015) Automatic Geometry Generation from Point Clouds for BIM, Remote Sensing, Vol. 7, pp. 11753-11775. DOI: 10.3390/rs7091175

Trimble (2017) From Design to Reality. Available via: https://www.tekla.com/uk [Accessed: October, 2017].

Underwood, J. and Isikdag, U. (2011) Emerging Technologies for BIM 2.0, Construction Innovation, Vol. 11, No. 3, pp. 252-258. DOI: 10.1108/14714171111148990 
Volk, R., Strengel, J. and Schultzmann, F. (2013) Building Information Modelling (BIM) for Existing Buildings - Literature Review and Future Needs, Automation in Construction, Vol. 38, pp. 109-127. DOI: http://dx.doi.org/10.1016/j.autcon.2013.10.023

Waheed, Z. and Fernie, S. (2009) Knowledge Based Facilities Management, Facilities, Vol. 27, No. 7/8, pp. 258-266. DOI: 10.1108/02632770910956111

Welle, B., Haymaker, J. and Rogers, Z. (2011) ThermalOpt: A Methodology for Automated BIM-based Multidisciplinary Thermal Simulation for Use in Optimization Environments, Building Simulation, Vol. 4, pp. 293-313. DOI: 10.1007/s12273-0110052-5

World Commission on Environment and Development (1987) Our Common Future, Oxford: Oxford University Press. ISBN: 019282080X.

Xu, Z., Zhang, Y. and Xu, X. (2016) 3D Visualization for Building Information Models Based upon IFC and WebGL Integration, Multimedia Tools and Applications, Vol. 75, pp. 17421-17441. DOI: 10.1007/s11042-016-4104-9

Xue, W., Wang, Y. and Man, Q. (2015) Research on Information Models for the Construction Schedule Management Based on the IFC Standard, Journal of Industrial Engineering and Management, Vol. 8, No. 3, pp. 615-635. DOI: http://dx.doi.org/10.3926/jiem.1283

Yang, J., Shi, Z. K. and Wu, Z. Y. (2016a) Towards Automatic Generation of As-built BIM: 3D Building Façade Modeling and Material Recognition from Images, International Journal of Automation and Computing, Vol. 13, No. 4, pp. 338-349. DOI: $10.1007 / \mathrm{s} 11633-016-0965-7$

Yang, Z., Ghahramani, A. and Becerik-Gerber, B. (2016b) Building Occupancy Diversity and HVAC (Heating, Ventilation, and Air Conditioning) Systems Efficiency, Energy, Vol. 109, pp. 641-649. DOI: 10.1016/j.energy.2016.04.099

Yung, P. and Wang, X. (2014) A 6D Model for the Automatic Assessment of Building Sustainability, International Journal of Advanced Robotic Systems, Vol. 11, No. 0, pp. 1-8. DOI: $10.5772 / 58446$ 
Table 1 - BIM Compliance Definition Comparison

\begin{tabular}{|c|c|c|c|c|c|c|c|}
\hline \multirow{2}{*}{$\begin{array}{l}\text { BIM compliance/ maturity } \\
\text { definitions }\end{array}$} & \multicolumn{7}{|c|}{ Author(s) } \\
\hline & 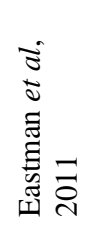 & 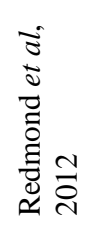 & 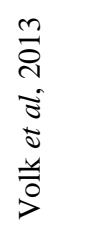 & 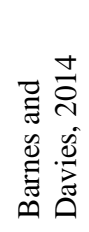 & 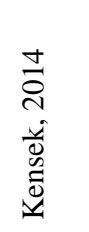 & 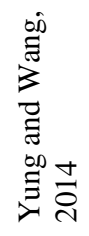 & 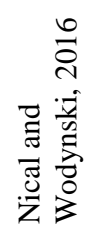 \\
\hline 3D - Object model & • & - & - & • & • & - & • \\
\hline 4D - Time & $\bullet$ & - & - & $\bullet$ & - & - & $\bullet$ \\
\hline 5D - Cost & - & - & - & - & - & • & $\bullet$ \\
\hline 6D - Operation & • & & & $\bullet$ & & & $\bullet$ \\
\hline $\begin{array}{l}\text { 6D - Operation and } \\
\text { Sustainability }\end{array}$ & & & & & - & & \\
\hline 6D - Sustainability & & $\bullet$ & & & & $\bullet$ & \\
\hline 7D - Sustainability & - & & & $\bullet$ & & & \\
\hline 8D - Safety & $\cdot$ & & & & & & \\
\hline
\end{tabular}


Table 2 - BIM Software Overview

\begin{tabular}{|c|c|c|}
\hline Software Function & Software package & Overview \\
\hline \multirow[t]{2}{*}{ Conceptual Design } & Rhino & $\begin{array}{l}\text { 3D modelling software not exclusively designed for architectural design. } \\
\text { Purportedly no upper limit on potential complexity of generated model } \\
\text { (Rhinoceros, 2017). }\end{array}$ \\
\hline & SketchUp & $\begin{array}{l}\text { 3D modelling software utilised by architects, designers, builders, makers } \\
\text { and engineers. Software is focused upon simplifying technical user } \\
\text { requirements in order to aid the creation of innovative 3D designs } \\
\text { (SketchUp, 2017). }\end{array}$ \\
\hline \multirow[t]{6}{*}{ Design and Analysis } & Catia & $\begin{array}{l}\text { 3D modelling software developed in context to the simulated real-life } \\
\text { performance of the generated 3D product. Multi-purpose, utilised in } \\
\text { various industries (Dassault Systmems, 2017). }\end{array}$ \\
\hline & MicroStation & $\begin{array}{l}\text { 3D modelling software with advanced parametric modelling capabilities } \\
\text { focusing on multidisciplinary project delivery. Focused towards BIM and } \\
\text { the built environment as opposed to cross-industry application (Bentley, } \\
\text { 2017). }\end{array}$ \\
\hline & MagiCAD & $\begin{array}{l}\text { Mechanical, electrical and piping design modelling for the AECO sector. } \\
\text { Focused upon the integration of an extensive BIM library containing } \\
\text { parametric data (MagiCAD, 2017). }\end{array}$ \\
\hline & Revit & $\begin{array}{l}\text { Software developed specifically for BIM to offer a multidisciplinary and } \\
\text { collaborative design environment (Autodesk, 2017a). }\end{array}$ \\
\hline & $\begin{array}{l}\text { Trimble (formerly } \\
\text { Tekla) }\end{array}$ & $\begin{array}{l}\text { Software offering intelligent 3D modelling specifically for the AECO } \\
\text { sector. Particular focus upon collaboration and efficiency (Trimble, 2017). }\end{array}$ \\
\hline & Ecotect & $\begin{array}{l}\text { A constituent of Autodesk. 3D modelling software focused upon the design } \\
\text { and performance of green buildings. Discontinued due to intention to } \\
\text { incorporate features into Autodesk - notably no replacement to date } \\
\text { (Autodesk, 2014; Autodesk, 2016). }\end{array}$ \\
\hline $\begin{array}{l}\text { Fabrication and } \\
\text { Construction }\end{array}$ & Navisworks & $\begin{array}{l}\text { A constituent of Autodesk. Allows architecture, engineering and } \\
\text { construction professionals a holistic view of multiple integrated models. } \\
\text { Focused on delivering greater control of project outcomes to development } \\
\text { stakeholders (Autodesk, 2017b). }\end{array}$ \\
\hline \multirow[t]{2}{*}{$\begin{array}{l}\text { Operation and } \\
\text { Maintenance }\end{array}$} & EcoDomus & $\begin{array}{l}\text { A real-time 3D facilities software package offering a user friendly interface } \\
\text { for facility managers. A single-source database is utilised to collect all } \\
\text { relevant information in one location for use over a building's entire life- } \\
\text { cycle (ecodomus, 2015). }\end{array}$ \\
\hline & ArchiFM & $\begin{array}{l}\text { 3D modelling software focused upon an entire life-cycle view of } \\
\text { development. Utilised by architects, designers, engineers and builders } \\
\text { within the AECO sector. Particularly focused on utilising BIM (Graphisoft, } \\
\text { 2017). }\end{array}$ \\
\hline
\end{tabular}


Figure 1 - Componential Synthesis

AECO context Future research suggestions

\section{Academic citations}

\begin{tabular}{|c|c|c|c|c|c|c|c|c|c|}
\hline & i & ii & iii & iv & $\mathbf{v}$ & vi & vii & viii & \\
\hline A & 2 & 1 & 0 & 1 & 4 & 3 & 0 & 0 & {$[29],[42],[43],[46],[48],[68],[73]$} \\
\hline B & 0 & 1 & 0 & 3 & 0 & 0 & 0 & 1 & {$[1],[2],[4],[26]$} \\
\hline C & 3 & 3 & 1 & 0 & 0 & 0 & 1 & 0 & {$[56],[58],[110],[118],[123]$} \\
\hline D & 0 & 0 & 0 & 1 & 0 & 3 & 1 & 6 & {$[14],[16],[18],[24],[33],[40],[64],[94],[96],[119],[121]$} \\
\hline $\mathbf{E}$ & 5 & 2 & 1 & 3 & 3 & 5 & 0 & 1 & {$[5],[15],[21],[52],[57],[60],[61],[66],[70],[77],[78],[84],[91]$} \\
\hline $\mathbf{F}$ & 0 & 0 & 0 & 0 & 1 & 0 & 0 & 0 & [75] \\
\hline G & 1 & 3 & 0 & 0 & 0 & 1 & 4 & 0 & {$[50],[59],[71],[74],[95],[97],[108],[113],[120]$} \\
\hline $\begin{array}{l}\text { Total } \\
\text { suggestions }\end{array}$ & 11 & 10 & 2 & 8 & 8 & 12 & 6 & 8 & \\
\hline $\begin{array}{l}\text { Distribution } \\
\text { amongst } \\
\text { journal } \\
\text { publications }\end{array}$ & $\begin{array}{c}\text { AEI }-9.09 \% \\
\text { AC }-27.27 \% \\
\text { BEPAM }-9.09 \% \\
\text { JFM }-9.09 \% \\
\text { JITC }-9.09 \% \\
\text { JME }-18.18 \% \\
\text { MTA }-9.09 \% \\
\text { SS }-9.09 \%\end{array}$ & $\begin{array}{c}\text { AEI }-10.00 \% \\
\text { AC - } 20.00 \% \\
\text { BEPAM }-20.00 \% \\
\text { F- } 10.00 \% \\
\text { IJSPM }-10.00 \% \\
\text { JFM }-10.00 \% \\
\text { JITC }-10.00 \% \\
\text { PE - } 10.00 \%\end{array}$ & $\begin{array}{c}\text { F- } 50.00 \% \\
\text { MTA }-50.00 \%\end{array}$ & $\begin{array}{c}\text { AEI }-12.50 \% \\
\text { BEPAM }-25.00 \% \\
\text { BE }-12.50 \% \\
\text { CI }-12.50 \% \\
\text { F- } 12.50 \% \\
\text { PE }-12.50 \% \\
\text { SS }-12.50 \%\end{array}$ & $\begin{array}{c}\text { AC }-12.50 \% \\
\text { BEPAM }-12.50 \% \\
\text { CME }-12.50 \% \\
\text { ECAM }-12.50 \% \\
\text { F }-12.50 \% \\
\text { JCEM }-12.50 \% \\
\text { JME }-12.50 \% \\
\text { RSER }-12.50 \%\end{array}$ & $\begin{array}{c}\text { AC }-33.33 \% \\
\text { BEPAM }-8.33 \% \\
\text { BE }-8.33 \% \\
\text { ECAM }-8.33 \% \\
\text { F- } 16.67 \% \\
\text { IJMPB }-8.33 \% \\
\text { JCEM }-8.33 \% \\
\text { JFM }-8.33 \%\end{array}$ & $\begin{array}{c}\text { BEPAM - } 16.67 \% \\
\text { CI }-16.67 \% \\
\text { F }-33.33 \% \\
\text { JME }-16.67 \% \\
\text { LME }-16.67 \%\end{array}$ & $\begin{array}{c}\text { AC- }-12.50 \% \\
\text { BS }-12.50 \% \\
\text { IC }-12.50 \% \\
\text { JCP }-12.5 \% \\
\text { PE }-25.00 \% \\
\text { RCR }-12.50 \% \\
\text { SS }-12.50 \%\end{array}$ & \\
\hline
\end{tabular}

\begin{tabular}{ll}
\hline \multicolumn{2}{l}{ Suggested future research } \\
\hline i & Improvement to industry data interoperability \\
\hline ii & Increase collaborative working (organisational level) \\
\hline iii & Increase collaborative working (individual/actor level) \\
\hline iv & Refinement of processes and management practices \\
\hline V & Resolution of implementation difficulties \\
\hline vi & Increase performance measurement and analysis \\
\hline vii & Increase to industry skill levels \\
\hline viii & Increase environmental sustainability of development \\
\hline
\end{tabular}

\begin{tabular}{ll}
\hline Digital AECO context \\
\hline A & BIM implementation \\
\hline B & Generative design \\
\hline C & BIM data implications \\
\hline D & BIM performance analysis \\
\hline E & BIM for asset management \\
\hline F & Design for maintenance \\
\hline G & $\begin{array}{l}\text { Knowledge transfer and } \\
\text { skill requirements }\end{array}$ \\
\hline
\end{tabular}

\begin{tabular}{llll} 
Journal & publications & & \\
\hline AEI & Advanced Engineering Informatics & JCP & Journal of Cleaner Production \\
\hline AC & Automation in Construction & JCEM & Journal of Construction Engineering and Management \\
\hline BEPAM & Built Environment Project and Asset Management & JFM & Journal of Facilities Management \\
\hline BS & Building Simulation & JITC & Journal of Information Technology in Construction \\
\hline BE & Building and Environment & JME & Journal of Management in Engineering \\
\hline Cl & Construction Innovation & LME & Leadership and Management in Engineering \\
\hline CME & Construction Management and Economics & MTA & Multimedia Tools and Applications \\
\hline ECAM & Engineering, Construction and Architectural Management & PE & Procedia Engineering \\
\hline F & Facilities & RSER & Renewable and Sustainable Energy Reviews \\
\hline IC & Informes de la Construcción & RCR & Resources, Conservation and Recycling \\
\hline IJMPB & International Journal of Managing Projects in Business & SS & Structural Survey \\
\hline IJSPM & International Journal of Strategic Property Management & & \\
\hline
\end{tabular}


Figure 2 - Obstacles to BIM Integrated Asset Management in Practice
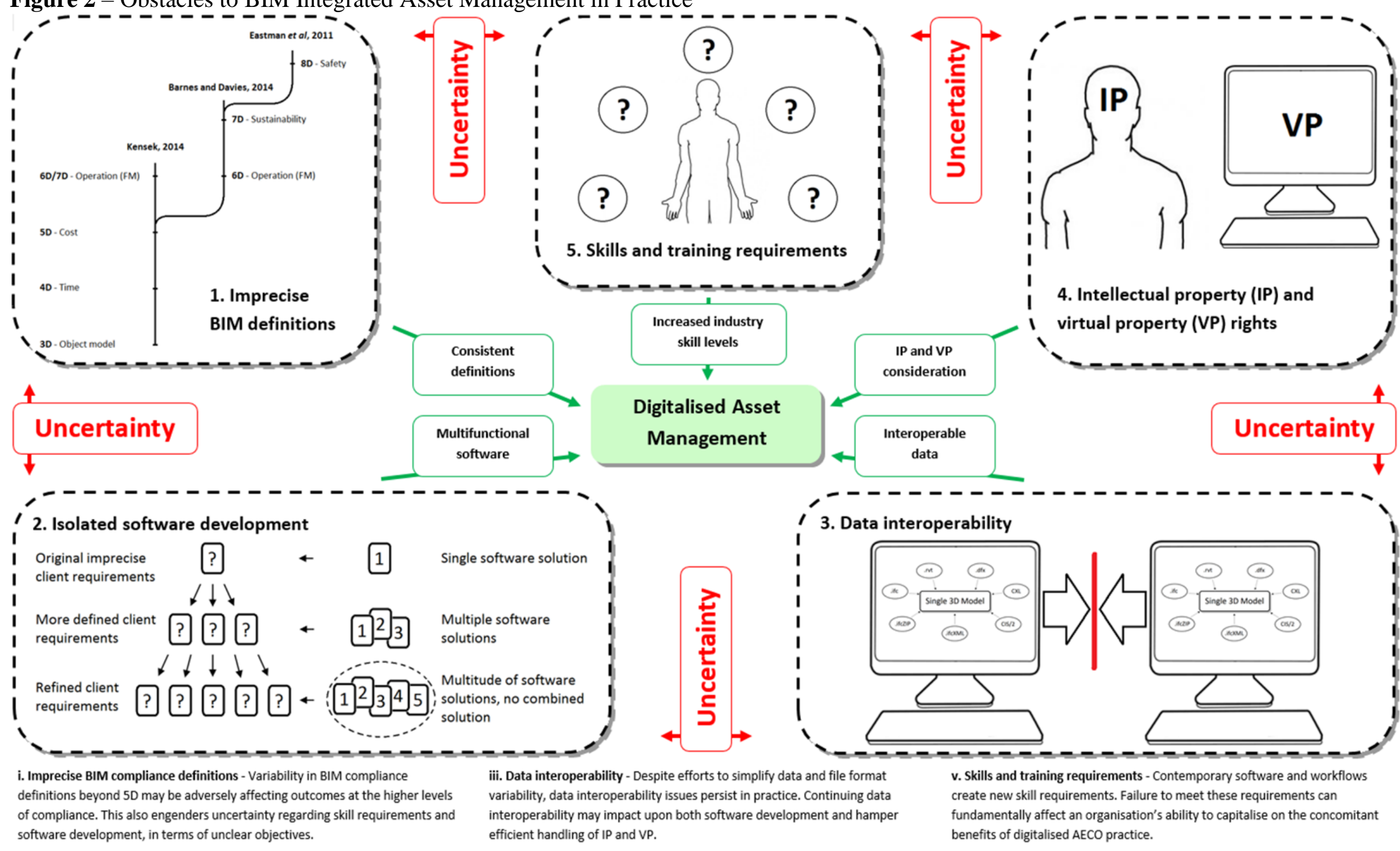

ii. Isolated software development - 3D modelling software is often developed

iv. IP and VP rights - A digitalised AECO sector makes use of large quantities of

in isolation. This may affect both efforts to establish consistent industry wide data owned by various stakeholders. Inappropriate handling of such data may definitions and resolve data interoperability issues.

exacerbate interoperability issues whilst increasing skill and training

requirements. 